\title{
Sexuality Among Older Adults
}

ISSN: 2578-0093

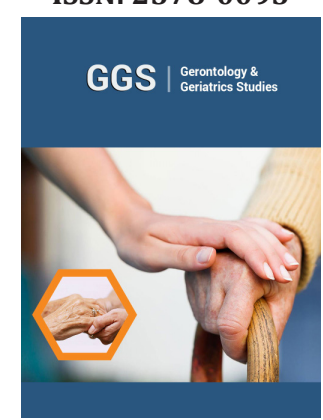

*Corresponding author: Milton Roberto FurstCrenitte, Department of Gerontology, Italy

Submission: 眥 May 25, 2020

Published: 眥 November 06, 2020

Volume 6 - Issue 3

How to cite this article: Milton Roberto FurstCrenitte. Sexuality Among Older Adults. Gerontol \& Geriatric stud. 6(3). GGS. 000637. 2020.

DOI: $10.31031 /$ GGS.2020.06.000637

Copyright@ Milton_Roberto FurstCrenitte, This article is distributed under the terms of the Creative Commons Attribution 4.0 International License, which permits unrestricted use and redistribution provided that the original author and source are credited.

\author{
Milton Roberto FurstCrenitte* \\ Department of Gerontology, Italy
}

\section{Opinion}

Gerontology, the science that studies aging, has advanced a lot in the last decades on the myth of "asexual ageing", starting to legitimize the inclusion of sexuality in this phase of people's lives. However, despite all the efforts of specialists, several social constructions still deprive the elderly of love, sexuality, and pleasure [1]. It is true that over the years some physiological changes occur in everyone's bodies, such as the reduction of vaginal lubrication in women or the decline in the intensity of orgasm in men. However, some prejudices lead many to believe that these changes are the main causes of dysfunctions in sexuality [2]. Rather than trying only to treat such changes as "abnormal", it is important that society discuss the barriers that limit the expression of affection and love in old age. It is undeniable that some technologies like the advent of medications for erectile dysfunction have benefits. However, geriatrics and gerontologists must understand the obstacles of the culturally possible, in order to reduce suffering and anguish at this stage of life [3].

In other words, Carole Vance, an anthropologist who discusses in her analyzes about the "Theory of Social Construction", argues that "the physiology of orgasm and penile erection explain as little about the sexual scheme of a culture as the auditory reach of the human ear explains music" [4]. Another question arises along these lines: about what it is and how we achieve sexual enjoyment. Thus, on the one hand, it is necessary to understand that penetration is not the only source of satisfaction. For this reason, another important debate falls on the "de-genitalization of pleasure", allowing the elderly to discover numerous other pleasurable areas in their bodies and to understand that the most important organ for the expression of sexuality is between their ears [5]. On the other hand, it is also worth arguing that sexuality is not just about the sexual act, going far beyond that. And in the example of love, there are countless ways to manifest it. It can be experienced by touch, affection, developed social relationships or the way the individual desires [5].

However, much of this relevant debate boils down to just one form of experimentation, thus maintaining a heterosexual normativity and an invisibility to the ageing of lesbians, gays, bisexuals and transgender people (LGBT) [6]. Unfortunately, they express greater risks of living alone, having no children and not having someone to call in case of an emergency [7-9]. In addition, some issues potentially related to the lack of trust in health services and the fear of discrimination in these places make these people stop looking for them or going only in emergencies, and thus, expressing inequalities in healthcare access $[8,10]$. Due to these arguments, the discussion about expressions of affection and love in older adults must also take ownership of what the authors of the feminist movement produced in the field of knowledge about gender and sexual oppression.

It is interesting to note that if elderly men are afraid of being considered naughty, indecent or degenerate for publicly exposing their affections and desires, this situation may be even worse for older women, whose learning about their own sexuality was guided by more moral codes strict. For this reason, the elderly suffers various repressions, not only from the youngest, but also from contemporary folks [1]. In this way, the title "Feminism is for everyone" in the book of Bell Hooks, an important black feminist activist, summarizes that the problem is not men, but patriarchy, sexism and male domination. For the author, such forms of oppression are harmful even in the life and in the construction of the self-esteem of boys and men, since 
many feels disturbed by the nature of their identities [11]. She adds that the feminist view that adheres to feminist masculinity, that loves boys and men and demands, in their name, all the desired rights for girls and women, can also renew the perception of what it is to be a man in society [11].

Thus, this thinking can be liberating even for elderly heterosexual men. For them, there is the possibility of reframing relationships in ageing process and freeing themselves from existential anxieties that haunt and question the male role from the occurrence of "sexual impotence" [12]. Furthermore, sexuality is an issue that should not be a taboo in society. Recalling that taboos create prejudices, which produce violence. And these generate suffering [13]. Finally, it is worth reflecting that reviewing the negative stereotypes of aging also has a liberating character and can help everyone to develop active and successful aging, assuming that sexuality is part of these strategies [1]. In this sense, the following quote exemplifies this idea: "The expressions of affection, the fantasies, the desire to be seduced and seduced, are present in the lives of the elderly as in any other stage of life, although they are not always presented in the same way. Rescuing the old man's right to a sexual life implies being able to think of love in its forms of libidinal transformation, that is, other forms of love, which pass through tenderness, through physical contacts that erogenize the body, such as looking, touching, voice, rediscovering the first forms of human love. The old man does not stop loving but reinvents loving forms" [14].

\section{References}

1. Debert G, Brigeiro M (2012) Fronteiras de gênero e a sexualidade na velhice. Rev Bras Ciências Sociais 27(80): 37-54.

2. Childs JM (2019) Aging and sexuality. Dialog 58(4): 269-276.
3. Ressel LB, Gualda DM (2003) A sexualidade como uma construção cultural: reflexões sobre preconceitos e mitos inerentes a um grupo de mulheres rurais. Rev Esc Enferm USP 37(3).

4. Vance CS (1989) Social construction theory: Problems in the history of sexuality. Homosex which Homosex.

5. Creusa T, Negreiros M (2004) Sexualidade e gênero no envelhecimento. Pró-reitoria Ext da Univ Fed Flum.

6. Crenitte MRF, Miguel DF, Filho WJ (2019) Abordagem das particularidades da velhice de lésbicas, gays, bissexuais e transgêneros/ An approach to the peculiarities of lesbian, gay, bisexual, and transgender aging. Geriatr Gerontol Aging 13(1): 50-56.

7. Bradford JB, Putney JM, Shepard BL, Sass SE, Rudicel S, Ladd H, et al. (2016) Healthy aging in community for older lesbians. LGBT Heal 3(2): 109-115.

8. Shankle MD, Maxwell CA, Katzman ES, Landers S (2003) An invisible population: older lesbian, gay, bisexual, and transgender individuals. Clin Res Regul Aff 20(2): 159-182.

9. Bauer M, McAuliffe L, Nay R (2007) Sexuality, health care and the older person: an overview of the literature. Int J Older People Nurs 2(1): 6368.

10. Baker K, Beagan B (2014) Making assumptions, making space: An anthropological critique of cultural competency and its relevance to queer patients. Med Anthropol Q 28(4): 578-598.

11. Hooks B (2000) Feminism is for everybody: Passionate politics. Cambridge MA: South End Press, USA.

12. Debert GG, Simões JA, Henning CE (2016) Entrelaçando gênero, sexualidade e curso da vida: Apresentação e contextualização. Sociedade e Cultura 19(2).

13. Jay T (2009) The utility and ubiquity of taboo words. Perspect Psychol Sci 4(2): 153-161.

14. Santos SS dos, Carlos SA (2003) Sexualidade e amor na velhice. Estud interdiscip Envelhec, pp.22-23. 